\title{
Analisis Longitudinal pada Data Pasien Diabetes Melitus
}

\author{
Mustika Wirastuti ${ }^{(1)}$, A'yunin Sofro, Ph.D ${ }^{(2)}$ \\ ${ }^{1,2)}$ Universitas Negeri Surabaya \\ J1. Ketintang, Ketintang, Kec. Gayungan, Surabaya 60231 \\ e-mail: mustikawirastuti@gmail.com, ayuninsofro@unesa.ac.id
}

\begin{abstract}
ABSTRAK
Diabetes melitus banyak dikenal orang sebagai penyakit gula darah. Orang dapat dikatakan menderita diabetes melitus jika kadar gula darah yang melebihi normal yaitu gula darah sewaktu $\geq 200$ $\mathrm{mg} / \mathrm{dl}$, kadar gula darah puasa $\geq 120 \mathrm{mg} / \mathrm{dl}$ dan kadar gula darah 2 jam sesudah makan $\geq 200 \mathrm{mg} / \mathrm{dl} \mathrm{serta}$ kadar Glycated hemoglobin $(\mathrm{HbA1c})<7 \%$. Faktor-faktor yang diduga penyebab diabetes melitus adalah usia, jenis kelamin, obesitas dan pengaruh obat penurun diabetes melitus. Obesitas dapat dilihat dari hasil nilai $A$ Body Shape Index (ABSI). Faktor-faktor penyebab penyakit diabetes melitus diambil dari variabel-variabel dari data IFLS4 dan IFLS5 yang bersifat longitudinal. Penelitian ini menganalisis tentang model untuk mengetahui bagaimana pengaruh faktor-faktor penyebab diabetes melitus dari waktu ke waktu. Hasilnya menunjukkan bahwa terjadi pengaruh yang signifikan antara variabel waktu pengukuran dan pengaruh obat penurun diabetes melitus. Semakin sedikit waktu pengukuran dan dengan banyak orang tidak mengonsumsi obat penurun diabetes maka akan semakin banyak pula orang yang menderita penyakit diabetes melitus.
\end{abstract}

Kata kunci : Diabetes melitus, faktor, IFLS, kadar gula darah, longitudinal data.

\section{ABSTRACT}

Diabetes mellitus is widely known as a blood sugar disease. People can be said to suffer from diabetes mellitus if blood sugar levels exceed normal, blood sugar when $\geq 200 \mathrm{mg} / \mathrm{dl}$, fasting blood sugar levels $\geq 120 \mathrm{mg} / \mathrm{dl}$, blood sugar levels 2 hours after meals $\geq 200 \mathrm{mg} / \mathrm{dl}$ and Glycated hemoglobin (HbAlc) levels $<7 \%$. Factors suspected of causing diabetes mellitus are age, gender, obesity and the effect of diabetes mellitus lowering medicines. Obesity can be seen from the results of the A Body Shape Index (ABSI) value. The factors that cause diabetes mellitus are taken from variables from IFLS4 and IFLS5 data that are longitudinal. This study analyzes the model to find out how the factors that cause diabetes mellitus influence over time. The results showed that there was a significant influence between observation time variable and the effect of diabetes mellitus lowering medicines. The more people who consume diabetes lowering medicines, the more people will suffer from diabetes mellitus.

Keywords : Blood sugar levels, Diabetes mellitus, factors, IFLS, , longitudinal data

\section{PENDAHULUAN}

World Health Organization (WHO) memprediksi bahwa jumlah penderita diabetes di Indonesia akan menduduki peringkat ke lima pada tahun 2025 dengan prediksi jumlah penderita sebanyak 12,4 jiwa. Saat ini, penderita diabetes melitus diperkirakan sudah mencapai angka 9,1 juta orang penduduk. Data tersebut menjadikan Indonesia menduduki peringkat ke-5 di dunia dengan penderita diabetes melitus tertinggi pada tahun 2013. Penyakit diabetes melitus merupakan salah satu penyebab utama penyakit tidak menular atau 2,1\% dari seluruh kematian yang terjadi. Kasus diabetes melitus di dunia diperkirakan sebanyak 90\% merupakan diabetes Tipe II. Menurut Riskesdas, Provinsi Jawa Timur dengan prevelensi penderita diabetes melitus sebesar 2,1\% dengan menempati urutan ke-9 (Susanti \& Bistara, 2018).

Penyakit diabetes melitus banyak dikenal orang sebagai penyakit yang erat kaitannya dengan 
asupan makanan. Asupan makanan seperti karbohidrat atau gula, protein, lemak, dan energi yang berlebihan dapat menjadi faktor resiko awal kejadian diabetes melitus. Semakin berlebihan asupan makanan maka semakin besar pula kemungkinan akan menyebabkan diabetes melitus. Karbohidrat akan dicerna dan diserap dalam bentuk monosakarida, terutama gula. Penyerapan gula menyebabkan peningkatan kadar gula darah dan mendorong peningkatan sekresi hormon insulin untuk mengontrol kadar gula darah (Susanti \& Bistara, 2018). Salahnya pola makan pada masyarakat tersebut juga menyebabkan ketidakseimbangan dalam tubuh hingga menjadi salah satu penyebab obesitas dan juga meningkatkan gula darah yang menjadi faktor dari diabetes.

Sebuah fakta dari Riset Kesehatan Dasar (Riskesdas) tahun 2007 hingga 2010 membuktikan bahwa prevalensi overweigt atau kelebihan berat badan dan obesity atau obesitas di Indonesia pada umur dewasa semakin meningkat dari $19,8 \%$ pada 2007 hingga $23 \%$ pada 2010 (Nugroho \& Wijayanti, 2018). Obesitas dapat dilihat dari nilai Indeks Masa Tubuh (IMT).

Ada beberapa penelitian yang mengevaluasi hubungan antara pola makan dan diabetes melitus serta nilai IMT dan diabetes melitus. Dalam penelitian ini mengeksplorasi jalur dari $A$ Body Shape Index (ABSI) sebagai tolok ukur obestitas. Orang yang sudah dinyatakan memiliki gula darah tinggi banyak dianjurkan untuk mengonsumsi obat penurun diabetes yang tujuannya dapat mengontrol kadar gula darah hingga batas normal. Pada penelitian ini akan dicari faktor-faktor yang mempengaruhi penyakit diabetes melitus.

Data yang digunakan diambil dari data Indonesia Family Life Survey (IFLS) pada tahun 2007 dan 2014. Pada tahun 2007 diambil dari data IFLS4 dan untuk 2014 diambil dari data IFLS5. IFLS sendiri adalah suatu survei yang dilakukan pada beberapa daerah di Indonesia dengan beberapa aspek penelitian. IFLS bersifat longitudinal dengan desain waktu penelitian setiayang digunakan, dimulai dari IFLS pada tahun 1993 (IFLS1) dilanjutkan tahun 1997 (IFLS2), 2000 (IFLS3), 2007 (IFLS4), dan 2014 (IFLS5).

Dalam pengukuran berulang dan dengan waktu yang telah ditentukan ini biasanya disebut dengan studi longitudinal. Tujuan dari analisis data longitudinal adalah untuk mempelajari bagaimana perubahan subjek yang diamati dari waktu ke waktu (Liu, 2016). Selain dapat digunakan untuk melihat perubahan, data longitudinal juga dapat digunakan untuk melihat variasi perubahan di antara individu (Danardono, 2015). Pengamatan yang dilakukan berulang-ulang terhadap subjek mengakibatkan respon yang diperoleh satu dengan yang sebelumnya, atau satu dengan berikutnya akan saling berhubungan (Diggle, Heagerty, Liang, \& Zeger, 2002). Misalnya, dalam studi kedokteran dimana individu yang sama diamati dari waktu ke waktu yang mengakibatkan adanya hubungan diantara pengamatan dari individu yang sama. Namun dengan pengukuran yang dilakukan berulang tersebut dikhawatirkan adanya data yang tidak teramati (unobserveb). Oleh karena itu, penelitian seperti ini tidak cocok dianalisis dengan metode regresi linear biasa sehingga metode regresi ini dikembangkan lagi dengan menambahkan random effects pada modelnya yang disebut dengan model linear campuran atau linear mixed model.

Ada bebrapa penelitian yang menggunakan data pada IFLS, salah satu contohnya adalah penelitian yang dilakukan oleh Isaura dkk., yang melakukan analisis mengenai faktor penyakit hipertensi dengan estimasi menggunakan Generalized Estimation Equation (GEE) (Isaura, Chen, \& Yang, 2018). Ada beberapa penelitian pada analisis longitudinal yang lain yang menggunakan pendekatan linear mixed model (LME), dalam penelitian yang dilakukan Nirmala dkk., dimana mereka mengaplikasikan General Linear Mixed Model (GLMM) pada data longitudinal kadar trombosit demam berdarah dengue (Nirmala, Kuntoro, \& Notobroto, 2013). Linear Mixed Model untuk analisis longitudinal data juga digunakan dalam penelitian Pusponegoro dkk., dengan studi simulasi perbedaan pertumbuhan anak (Pusponegoro, Rachmawati, Notodiputro, \& Sartono, 2017).

Dari rujukan beberapa penelitian di atas, pada penelitian ini akan digunakan pendekatan Linear Mixed Models untuk analisis longitudinal pada data yang diambil dari IFLS. Dengan data yang akan dijadikan variabel adalah waku pengukuran, usia, jenis kelamin, nilai ABSI dan pengonsumsian obat penurun diabetes, untuk mendeteksi individu yang menderita diabetes melitus dengan melihat kadar gula dalam darah setiap pengukurannya yang dilihat dari kadar Glycated hemoglobil (HbA1c) yang sering digunakan untuk kontrol glikemik jangka panjang, serta digunakan Restricted Maximum Likelihood (REML) untuk estimasi parameter karena REML bersifat unbiased sedangkan estimasi Maximum Likelihood (MLE) diketahui biased. Selanjutnya data dimodelkan dari hasil estimasi parameter kemudian diinterpresikan hasil model yang diperoleh. 
J Statistika Vol. 12, No. 1,(2019), Hal. 13-19

\section{METODE PENELITIAN}

Data yang digunakan dalam penelitian ini adalah data sekunder yang diambil dari data hasil survei IFLS4 tahun 2007 dan IFLS5 tahun 2014. Data diperoleh dari IFLS pada tahun 2007 dan 2014 di Jawa Timur, dengan data yang diambil terdiri dari perempuan dan laki-laki yang sudah mengikuti survei baik berupa tatap muka secara langsung dan juga pengisian kuisioner selama dua kali pengukuran tersebut. Dengan kategori data yang diambil adalah tidak ada data yang hilang pada data usia, jenis kelamin, pengukuran antropometrik, kadar HbA1c dan keterangan pengonsumsian obat penurun diabetes. Dari hasil pengumpulan data pada IFLS yang sesuai dengan kriteria yang telah ditentukan, diperoleh sebanyak 293 responden.

Variabel respon yang digunakan dalam penelitian ini adalah kadar HbA1c $\left(y_{i j}\right)$. Dan untuk variabel independen yang digunakan adalah waktu pengukuran $\left(X_{1}\right)$, usia $\left(X_{2}\right)$, jenis kelamin $\left(X_{3}\right)$, hasil nilai ABSI $\left(X_{4}\right)$, dan pengonsumsian obat penurun diabetes $\left(X_{5}\right)$.

Metode analisis yang digunakan dalam penelitian ini adalah analisis longitudinal dengan pendekatan linear mixed model. Dengan langkah yang pertama adalah pembentukan spesifikasi model lalu dilanjutkan dengan estimasi parameter. Setelah diperoleh nilai parameter kemudian hasil nilai parameter dimasukan dalam spesifikasi model sehingga terbentuklah model dan dilakukan interpretasi hasil model. Selanjutnya dilakukan uji hipotesis untuk mengetahui pengaruh variabel independen terhadap variabel respon. Dalam penelitian ini data akan dimodelkan menjadi dua model dengan model 1 adalah model intersep acak dan model kedua adalah model intersep dan slop acak. Untuk mengetahui model yang terbaik digunakan kriteria pemilihan model terbaik menggunakan AIC. Dari uraian diatas maka tahapan metode analisis data yang digunakan yaitu:

1. Memodelkan data

Pada tahap ini data akan dimodelkan sesuai dengan model linear mixed model. Dengan data akan dimodelkan menjadi dua model khusus (Rizopoulus, 2012). Persamaan model tersebut adalah sebagai berikut:

Model 1 Data Longitudinal

Model intersep acak:

$$
\left\{\begin{aligned}
y_{i j}= & \beta_{0}+\beta_{1} t_{i j}+b_{i 0}+\varepsilon_{i j} \\
& b_{i 0} \sim \mathcal{N}\left(0, \sigma_{b}^{2}\right) \\
& \varepsilon_{i j} \sim \mathcal{N}\left(0, \sigma^{2}\right)
\end{aligned}\right.
$$

Model 2 Data Longitudinal

Model intersep dan slop acak: www.unipasby.ac.id

$$
\left\{\begin{array}{c}
y_{i j}=\beta_{0}+\beta_{1} t_{i j}+b_{i 0}+b_{i 1} t_{i j}+\varepsilon_{i j} \\
b_{i} \sim \mathcal{N}(0, G) \\
\varepsilon_{i j} \sim \mathcal{N}\left(0, \sigma^{2}\right)
\end{array}\right.
$$

Dengan,

$$
G=\left(\begin{array}{ll}
\sigma_{00} & \sigma_{01} \\
\sigma_{10} & \sigma_{11}
\end{array}\right)
$$

Langkah selanjutnya adalah mencari nilai parameter dengan estimasi parameter. Dalam penelitian ini digunakan estimasi Restricted Maximum Likelihood (REML). Setelah diketahui nilai parameter kemudian dimasukkan dalam spesifikasi model sehingga terbentuk model data longitudinal.

2. Uji Parameter

Dalam uji parameter dilakukan uji secara serentak dan parsial untuk mengetahui pengaruh variabel independen terhadap variabel respon. Pada pengujian secara serentak dilakukan menggunakan uji likelihood ratio yang dinotasikan $G$ serta statistik uji mengikuti ditribusi chi-square. Dengan hipotesisnya adalah:

$\mathrm{H}_{0}: \beta_{1}=\beta_{2}=\cdots=\beta_{\mathrm{p}}=0$ (Variabel independen secara serentak tidak signifikan terhadap variabel respon)

$\mathrm{H}_{1}$ : paling sedikit ada satu $\beta_{\mathrm{i}} \neq 0$ dengan $\mathrm{i}=$ $1,2, \ldots, p$ (dengan i adalah banyaknya variabel independen, paling sedikit ada satu variabel independen secara serentak signifikan terhadap variabel respon)

Untuk kepeutusan, menolak $H_{0}$ jika $G \geq \chi_{\alpha ; p}^{2}$ atau $p$-value $<\alpha$.

Untuk uji secara parsial dilakukan dengan uji t. Dengan hipotesisnya:

$\mathrm{H}_{0} \quad: \beta_{\mathrm{i}}=0$ (koefisien parameter ke-i tidak layak digunakan)

$\mathrm{H}_{1}$ : paling sedikit ada satu $\beta_{\mathrm{i}} \neq 0$ dengan $\mathrm{i}=$ $1,2, \ldots, p$ (dengan i adalah banyaknya variabel independen)

Tolak $H_{0}$ jika nilai $t_{\text {hitung }} \geq t_{\alpha / 2,(n-p-1)}$ atau $t_{\text {hitung }} \leq-t_{\alpha / 2,(n-p-1)}$ atau jika dibandingkan dengan nilai $p$-value yaitu $H_{0}$ ditolak jika $p$ value $\leq \alpha$.

3. Interpretasi Hasil Model

Model yang telah terbentuk akan diinterprestasi hubungan antara variabel yang signifikan.

4. Pemilihan model terbaik

Model terbaik ditentukan dari nilai AIC (Akaike Information Criterion) yang paling kecil.

\section{HASIL DAN PEMBAHASAN}

A. Model 1 Data Longitudinal

Model 1 merupakan model sederhana dari linear mixed model yang mengasumsikan perkembangan rata-rata dalam waktu dan memuat 
random effect tunggal untuk setiap pasien (Rizopoulus, 2012). Model 1 ini sering disebut model dengan intersep acak. Sesuai dengan persamaan (1), maka spesifikasi modelnya:

$$
\left\{\begin{array}{c}
y_{i j}=\beta_{0}+\beta_{1}\left(X_{1}\right)_{i}+\beta_{2}\left(X_{2}\right)_{i}+\beta_{3}\left(X_{3}\right)_{i} \\
+\beta_{4}\left(X_{4}\right)_{i}+\beta_{5}\left(X_{5}\right)_{i}+b_{i 0}+\varepsilon_{i j} \\
b_{i 0} \sim \mathcal{N}\left(0, \sigma_{b}^{2}\right) \\
\varepsilon_{i j} \sim \mathcal{N}\left(0, \sigma^{2}\right)
\end{array}\right.
$$

Dengan $i=1,2, \ldots, 293$ dan $j=1,2$.

Model diatas mendalilkan bahwa kadar HbA1c dari semua pasien memiliki perkembangan yang sama persis dalam waktu, tetapi berbeda pada awal yaitu setiap pasien memiliki intersep sendiri dengan beberapa pasien mulai dengan kadar HbA1c yang lebih tinggi dan rendah. Jenis kasus khusus dari linear mixed model ini dikenal sebagai model intersep acak. Untuk rumus dalam argumen acak harus ditentukan nama variabel pengelompokkan, identifikasi pengukuran berulang yang termasuk dalam kelompok yang sama, disini kelompok adalah subjek atau pasien. Selanjutnya akan dicari nilai parameter. Setelah melakukan spesifikasi bentuk model 1 langkah selanjutnya adalah mencari nilai parameter dengan cara estimasi parameter. Parameter yang diestimasi merupakan parameter variabel independen. Di sini parameter akan diestimasi menggunakan Restricted Maximum Likelihood (REML). REML merupakan metode estimasi yang digunakan untuk mengestimasi parameter-parameter fixed effect dan variansi dalam linear mixed model (Putri, Padmadisastra, \& Winarni, 2017).

Hasil estimasi parameter model 1 dengan menggunakan software $\mathrm{R}$ dapat dilihat pada tabel 1 berikut:

Tabel 1. Estimasi Parameter Model 1 Data Longitudinal

\begin{tabular}{|l|c|c|c|c|c|}
\hline & Parameter & Estimasi & SE & $t$-value & $p$-value \\
\hline Fixed Effect & & & & & \\
\hline (intercept) & $\beta_{0}$ & 10,275199 & 0,638206 & 16,100139 & 0,0000 \\
\hline $\begin{array}{l}\text { Waktu } \\
\text { Pengukuran } \\
\left(X_{1}\right)\end{array}$ & $\beta_{1}$ & $-2,205592$ & 0,196990 & $-11,196483$ & $0,0000^{*}$ \\
\hline Usia $\left(X_{2}\right)$ & $\beta_{2}$ & 0,003077 & 0,011985 & 0,256775 & 0,7975 \\
\hline $\begin{array}{l}\text { Jenis Kelamin } \\
\left(X_{3}\right)\end{array}$ & $\beta_{3}$ & 0,222391 & 0,237624 & 0,935897 & 0,3501 \\
\hline ABSI $\left(X_{4}\right)$ & $\beta_{4}$ & 5,151179 & 4,871295 & 1,057456 & 0,2912 \\
\hline Obat $\left(X_{5}\right)$ & $\beta_{5}$ & 2,352570 & 0,675832 & 3,480997 & $0,0006 *$ \\
\hline Random Effect & & 1,219142 & & & \\
\hline $\begin{array}{l}\text { Standar } \\
\text { Deviasi } \\
\text { (individu) }\end{array}$ & & 2,118543 & & & \\
\hline Error & & & & & \\
\hline
\end{tabular}

*) signifikan pada $\alpha=5 \%$

Selanjutnya dilakuakn pengujian hipotesis. Model akan dilakukan pengujian hipotesis dengan uji serentak dan parsial untuk mengetahui pengaruh faktor-faktor yang diduga mempengaruhi penyakit diabetes melitus.

Model 1 dilakukan uji serentak untuk mengetahui faktor-faktor yang diduga mempengaruhi penyakit diabetes melitus secara serentak dengan hipotesis berikut :

$\mathrm{H}_{0}: \beta_{1}=\beta_{2}=\beta_{3}=\beta_{4}=\beta_{5}=0$ (variabel waktu pengukuran, usia, jenis kelamin, nilai ABSI, dan konsumsi obat tidak signifikan terhadap penyakit diabetes melitus)

$\mathrm{H}_{1}$ : paling sedikit ada satu $\beta_{\mathrm{i}} \neq 0$ dengan $\mathrm{i}=$ $1,2,3,4,5$ (paling sedikit ada satu dari variabel waktu pengukuran, usia, jenis kelamin, nilai ABSI, dan konsumsi obat signifikan terhadap penyakit diabetes melitus.

Daerah kritis: Tolak $\mathrm{H}_{0}$ jika $\mathrm{G} \geq \chi_{\alpha ; \mathrm{p}}^{2}$ atau p-value $<$ $\alpha$. Hasil uji serentak untuk model 1 , dari hasil output software $\mathrm{R}$ diperoleh nilai statistik uji $G=$ $128,66 \geq \chi_{\alpha ; p}^{2} \quad$ dan $\quad p-$ value $=0,0001<\alpha$. Dengan menggunakan $\alpha=5 \%$ didapat nilai statistik uji $G=128,66 \geq \chi_{\alpha ; p}^{2}=11,070$ dan $p-$ value $=0,0001<0,05$. Dari hasil statistik uji maka $H_{0}$ ditolak. Sehingga dapat disimpulkan bahwa minimal ada satu dari variabel independen yaitu waktu pengukuran, usia, jenis kelamin, nilai ABSI dan konsumsi obat signifikan terhadap penyakit diabetes melitus.

Selanjutnya dilakukan uji parsial untuk model 1 untuk mengetahui pengaruh dari masing-masing variabel independen terhadap penyakit diabetes melitus secara parsial dengan hipotesis berikut:

$\mathrm{H}_{0}: \beta_{\mathrm{i}}=0$

$\mathrm{H}_{1}: \beta_{\mathrm{i}} \neq 0$ dengan $\mathrm{i}=1,2,3,4,5$

Dengan kriteria jika nilai $\mathrm{p}-$ value $<\alpha=0,05$.

Hasil uji parameter secara parsial model 1 yang dilakukan pada software $\mathrm{R}$ dapat dilihat pada tabel 1. Berdasarkan hasil uji parameter secara parsial pada tabel 1 menunjukkan bahwa variabel independen yaitu waktu pengukuran $\left(\mathrm{X}_{1}\right)$ dan konsumsi obat $\left(\mathrm{X}_{5}\right)$ siginifikan terhadap model 1 . Sehingga dapat disimpulkan bahwa waktu pengukuran dan konsumsi obat adalah faktor-faktor yang mempengaruhi penyakit diabetes melitus karena memliki $\mathrm{p}-$ value $<\alpha$ dengan tingkat signifikansi $\alpha=5 \%$.

Berdasarkan tabel 1. yang merupakan hasil dari estimasi parameter maka bentuk model 1 adalah: 


$$
\left\{\begin{array}{c}
y_{i j}=10,27519-2,20559\left(X_{1}\right)_{i}+0,00307\left(X_{2}\right)_{i} \\
+0,22239\left(X_{3}\right)_{i}+5,15118\left(X_{4}\right)_{i} \\
+2,352570\left(X_{5}\right)_{i}+b_{i 0}+\varepsilon_{i j} \\
b_{i 0} \sim \mathcal{N}\left(0, \sigma_{b}^{2}\right) \\
\varepsilon_{i j} \sim \mathcal{N}\left(0, \sigma^{2}\right)
\end{array}\right.
$$

Dengan nilai $\sigma_{b}^{2}=1,219142$ dan nilai $\sigma^{2}=$ 2,118543.

Berdasarkan hasil pembentukan model 1, model 1 di atas menunjukkan bahwa peluang responden akan menderita penyakit diabetes melitus dipengaruhi oleh faktor waktu pengukuran dengan nilai koefisien sebesar $-2,205592$, usia dengan nilai koefisien 0,003077 , jenis kelamin dengan nilai koefisien 0,222391, nilai ABSI dengan koefisien 5,151179, dan pengonsumsian obat penurun diabetes dengan koefisien 2,352570.

Berdasarkan salah satu data yang diambil maka responden yang menderita penyakit diabetes melitus dipengaruhi oleh faktor waktu pengukuran, usia, jenis kelamin, ABSI, dan pengonsumsian obat penurun diabetes sebesar 8,2917516801 dengan data diambil pada responden dengan Id 218010002 pada pengukuran pertama, dimana $X_{1}=1, X_{2}=$ 62, $X_{3}=0, X_{4}=0,00609$, dan $X_{5}=0$.

Berdasarkan tabel 1 diketahui bahwa faktor waktu pengukuran dan pengonsumsian obat penurun diabetes yang berpengaruh secara signifikan terhadap penyakit diabetes melitus, dimana faktor waktu pengukuran dengan $p$-value sebesar 0,0000 dan pengonsumsian obat penurun diabetes dengan $p$-value sebesar 0,0006 lebih kecil dari $\alpha=5 \%$. Sehingga dapat disimpulkan bahwa semakin sedikit waktu pengukuran dan dengan banyak responden tidak mengonsumsi obat penurun diabetes maka akan semakin banyak pula responden yang menderita penyakit diabetes melitus.

\section{B. Model 2 Data Longitudinal}

Model 2 ini merupakan perluasan dari model 1, yang memungkinkan untuk spesifikasi yang lebih fleksibel dari struktur kovarian dengan intersep acak dan slop acak. Sesuai dengan persamaan (2), maka spesifikasi modelnya:

$$
\left\{\begin{array}{c}
y_{i j}=\beta_{0}+\beta_{1}\left(X_{1}\right)_{i}+\beta_{2}\left(X_{2}\right)_{i}+\beta_{3}\left(X_{3}\right)_{i} \\
+\beta_{4}\left(X_{4}\right)_{i}+\beta_{5}\left(X_{5}\right)_{i} \\
+b_{i 0}+b_{i 1}\left(X_{1}\right)_{i}+\varepsilon_{i j} \\
b_{i} \sim \mathcal{N}(0, G) \\
\varepsilon_{i j} \sim \mathcal{N}\left(0, \sigma^{2}\right)
\end{array}\right.
$$

Dengan $b_{i}=\left(b_{i 0}, b_{i 1}\right), \quad i=1,2, \ldots, 293$ dan $j=$ 1,2. Model ini menambahkan random effect dan mengasumsikan bahwa tingkat perubahan dalam kadar HbA1c berbeda dari pasien ke pasien. Maka dari itu, untuk spesifikasi model ditambahkan variabel waktu pengukuran pada random effect. Selanjutnya akan dicari nilai parameter.

Setelah melakukan spesifikasi bentuk model 2 langkah selanjutnya adalah mencari nilai parameter dengan cara estimasi parameter. Parameter yang diestimasi merupakan parameter variabel independen. Di sini parameter akan diestimasi menggunakan Restricted Maximum Likelihood (REML). REML merupakan metode estimasi yang digunakan untuk mengestimasi parameterparameter fixed effect dan variansi dalam linear mixed model.

Hasil estimasi parameter model 2 dengan menggunakan software $\mathrm{R}$ dapat dilihat pada tabel 2 berikut:

Tabel 2. Estimasi Parameter Model 2 Data Longitudinal

\begin{tabular}{|l|c|c|c|c|c|}
\hline & Parameter & Estimasi & SE & $t$-value & $p$-value \\
\hline Fixed Effect & $\beta_{0}$ & 10,514783 & 0,4262761 & 24,666605 & 0,0000 \\
\hline (intercept) & $\beta_{1}$ & $-2,083414$ & 0,1860933 & $-11,195534$ & $0,0000^{*}$ \\
\hline $\begin{array}{l}\text { Waktu } \\
\text { Pengukuran } \\
\left(X_{1}\right)\end{array}$ & $\beta_{2}$ & $-0,002341$ & 0,0079905 & $-0,293000$ & 0,7697 \\
\hline Usia $\left(X_{2}\right)$ & $\beta_{3}$ & 0,062066 & 0,1581197 & 0,392527 & 0,6950 \\
\hline $\begin{array}{l}\text { Jenis Kelamin } \\
\left(X_{3}\right)\end{array}$ & $\beta_{4}$ & 4,503903 & 2,4427150 & 1,843810 & 0,0662 \\
\hline ABSI $\left(X_{4}\right)$ & $\beta_{5}$ & 0,427394 & 0,8488260 & 0,503512 & 0,6150 \\
\hline Obat $\left(X_{5}\right)$ & 2,245989 & & & \\
\hline Random Effect & & 2,582911 & & & \\
\hline $\begin{array}{l}\text { Standar } \\
\text { Deviasi } \\
\text { (individu) }\end{array}$ & & 1,036742 & & & \\
\hline $\begin{array}{l}\text { Standar } \\
\text { Deviasi } \\
\text { (waktu } \\
\text { pengukuran) }\end{array}$ & & & & & \\
\hline Error & & & & & \\
\hline
\end{tabular}

*) signifikan pada $\alpha=5 \%$

Selanjutnya dilakuakn pengujian hipotesis. Model akan dilakukan pengujian hipotesis dengan uji serentak dan parsial untuk mengetahui pengaruh faktor-faktor yang diduga mempengaruhi penyakit diabetes melitus.

Model 2 dilakukan uji serentak untuk mengetahui faktor-faktor yang diduga mempengaruhi penyakit diabetes melitus secara serentak dengan hipotesis berikut :

$H_{0}: \beta_{1}=\beta_{2}=\beta_{3}=\beta_{4}=\beta_{5}=0$ (variabel waktu pengukuran, usia, jenis kelamin, nilai ABSI, dan konsumsi obat tidak signifikan terhadap penyakit diabetes melitus) 
$H_{1}$ : paling sedikit ada satu $\beta_{i} \neq 0$ dengan $i=$ $1,2,3,4,5$ (paling sedikit ada satu dari variabel waktu pengukuran, usia, jenis kelamin, nilai ABSI, dan konsumsi obat signifikan terhadap penyakit diabetes melitus.

Daerah kritis: Tolak $H_{0}$ jika $G \geq \chi_{\alpha ; p}^{2}$ atau $p$-value $<$ $\alpha$. Hasil uji serentak untuk model 2, dari hasil output software $\mathrm{R}$ diperoleh nilai statistik uji $G=$ $116,0938 \geq \chi_{\alpha ; p}^{2}$ dan $p$-value $=0,0001<\alpha$. Dengan menggunakan $\alpha=5 \%$ didapat nilai statistik uji $G=116,0938 \geq \chi_{\alpha ; p}^{2}=11,070$ dan $p$-value $=0,0001<0,05$. Dari hasil statistik uji maka $H_{0}$ ditolak. Sehingga dapat disimpulkan bahwa minimal ada satu dari variabel independen yaitu waktu pengukuran, usia, jenis kelamin, nilai ABSI dan konsumsi obat signifikan terhadap penyakit diabetes melitus.

Selanjutnya dilakukan uji parsial untuk model 2 untuk mengetahui pengaruh dari masing-masing variabel independen terhadap penyakit diabetes melitus secara parsial dengan hipotesis berikut:

$H_{0}: \beta_{i}=0$

$H_{1}: \beta_{i} \neq 0$ dengan $i=1,2,3,4,5$

Dengan kriteria jika nilai $p-$ value $<\alpha=0,05$.

Hasil uji parameter secara parsial model 2 yang dilakukan pada software $\mathrm{R}$ dapat dilihat pada tabel 2. Berdasarkan hasil uji parameter secara parsial pada tabel 2 di atas menunjukkan bahwa variabel independen yaitu waktu pengukuran $\left(X_{1}\right)$ siginifikan terhadap model 2 . Sehingga dapat disimpulkan bahwa waktu pengukuran adalah faktor-faktor yang mempengaruhi penyakit diabetes melitus karena memliki $p$-value $<\alpha$ dengan tingkat signifikansi $\alpha=5 \%$.

Berdasarkan tabel 2 yang merupakan hasil dari estimasi parameter maka bentuk model 2 adalah:

$$
\begin{gathered}
\left\{\begin{array}{c}
y_{i j}=10,51478-2,0834\left(X_{1}\right)_{i}-0,0023\left(X_{2}\right)_{i} \\
+0,062066\left(X_{3}\right)_{i}+4,503903\left(X_{4}\right)_{i} \\
+0,427394\left(X_{5}\right)_{i}+b_{i 0}+b_{i 1}\left(X_{1}\right)_{i}+\varepsilon_{i j} \\
b_{i} \sim \mathcal{N}(0, G) \\
\varepsilon_{i j} \sim \mathcal{N}\left(0, \sigma^{2}\right)
\end{array}\right. \\
\text { Dengan, } \operatorname{cov}(G)=\left(\begin{array}{cc}
2.245989 & 2.582911 \\
2.582911 & -0.959
\end{array}\right)
\end{gathered}
$$

dan nilai $\sigma^{2}=1.036742$.

Berdasarkan hasil pembentukan model 2, model 2 di atas menunjukkan bahwa peluang responden akan menderita penyakit diabetes melitus dipengaruhi oleh faktor waktu pengukuran dengan nilai koefisien sebesar $-2,083414$, usia dengan nilai koefisien $-0,002341$, jenis kelamin dengan nilai koefisien 0,062066, nilai ABSI dengan koefisien 4,503903, dan pengonsumsian obat penurun diabetes dengan koefisien 0,427394.

Berdasarkan salah satu data yang diambil maka responden yang menderita penyakit diabetes melitus dipengaruhi oleh faktor waktu pengukuran, usia, jenis kelamin, ABSI, dan pengonsumsian obat penurun diabetes sebesar 8,313655769 dengan data diambil pada responden dengan Id 218010002 pada pengukuran pertama, dimana $X_{1}=1, X_{2}=62$, $X_{3}=0, X_{4}=0,00609$, dan $X_{5}=0$.

Berdasarkan tabel 2 diketahui bahwa faktor waktu pengukuran yang berpengaruh secara signifikan terhadap penyakit diabetes melitus, dimana faktor waktu pengukuran dengan $p$ - value sebesar 0,0000 lebih kecil dari $\alpha=5 \%$. Sehingga dapat disimpulkan bahwa semakin sedikit waktu pengukuran maka akan semakin banyak pula responden yang menderita penyakit diabetes melitus.

C. Kriteria Pemilihan Model Terbaik

Pada penelitian ini akan digunakan nilai AIC untuk membandingkan model. Model terbaik adalah dengan nilai AIC yang lebih kecil dari model lain.

\begin{tabular}{|c|c|}
\hline & \\
\hline Model 1 & 2707952 \\
\hline Model 2 & 2472,818 \\
\hline
\end{tabular}
Hasil nilai AIC dapat dilihat pada tabel 3 berikut:

Tabel 3. Nilai AIC Model Data Longitudinal 1 dan

Nilai AIC diperoleh dari perhitungan pada persamaan (2.16). Dari hasil perhitungan AIC pada tabel 4.7 di atas, menunjukkan bahwa model 2 lebih baik dibandingkan model 1, karena nilai AIC model 2 lebih kecil dibandingkan dengan nilai AIC model 1.

\section{KESIMPULAN DAN SARAN}

Kesimpulan dari hasil analisis di atas adalah sebagai berikut:

1. Dari hasil estimasi parameter menggunakan analisis longitudinal diperoleh model sebagai berikut :

\section{Model 1 Data Longitudinal}

$$
\left\{\begin{array}{c}
y_{i j}=10,27519-2,20559\left(X_{1}\right)_{i}+0,00307\left(X_{2}\right)_{i} \\
+0,22239\left(X_{3}\right)_{i}+5,15118\left(X_{4}\right)_{i} \\
+2,352570\left(X_{5}\right)_{i}+b_{i 0}+\varepsilon_{i j} \\
b_{i 0} \sim \mathcal{N}\left(0, \sigma_{b}^{2}\right) \\
\varepsilon_{i j} \sim \mathcal{N}\left(0, \sigma^{2}\right)
\end{array}\right.
$$


Dengan nilai $\sigma_{b}^{2}=1,219142$ dan nilai $\sigma^{2}=$ 2,118543 .

\section{Model 2 Data Longitudinal}

$$
\left\{\begin{array}{c}
y_{i j}=10,51478-2,0834\left(X_{1}\right)_{i}-0,0023\left(X_{2}\right)_{i} \\
+0,062066\left(X_{3}\right)_{i}+4,503903\left(X_{4}\right)_{i} \\
+0,427394\left(X_{5}\right)_{i}+b_{i 0}+b_{i 1}\left(X_{1}\right)_{i}+\varepsilon_{i j} \\
b_{i} \sim \mathcal{N}(0, G) \\
\varepsilon_{i j} \sim \mathcal{N}\left(0, \sigma^{2}\right)
\end{array}\right.
$$

Dengan,

$$
\operatorname{cov}(G)=\left(\begin{array}{cc}
2.245989 & 2.582911 \\
2.582911 & -0.959
\end{array}\right)
$$

dan nilai $\sigma^{2}=1.036742$.

2. Dari hasil analisis pada model 1 diperoleh bahwa waktu pengukuran dan pengonsumsian obat penurun diabetes berpengaruh terhadap pasien diabetes melitus dari waktu ke waktu.

3. Dari hasil analisis model 2 waktu pengukuran berpengaruh terhadap pasien diabetes melitus dari waktu ke waktu.

4. Dari hasil perhitungan AIC, model 2 yaitu model dengan intersep dan slop acak lebih baik dibandingkan dengan model 1 yaitu model dengan intesep acak, karena nilai AIC model 2 lebih kecil dibandingkan nilai AIC model 1.

Saran yang dapat diberikan adalah sebagai berikut:

Analisis longitudinal menggunakan pendekatan LME ini dapat dikembangakan lagi dalam beberapa model dan metode. Dalam skripsi ini hanya menganalisis data longitudinal yang lengkap atau tidak ada data yang hilang dan beberapa kasus banyak ditemui data longitudinal yang tidak lengkap atau terdapat data yang hilang (missing data). Maka penulis selanjutnya dapat membahas dengan kasus adanya data yang hilang pada data longitudinal dengan metode yang berbeda salah satu contohnya yaitu dengan joint modeling data longitudinal dan survival serta masih banyak yang lainnya.

\section{DAFTAR PUSTAKA}

Danardono. (2015). Analisis Data Longitudinal. Yogyakarta: Gadjah Mada University Press.

Diggle, P. J., Heagerty, P., Liang, K.-Y., \& Zeger, S. L. (2002). Analysis of Longitudinal Data. Oxford: Oxford University Press.
Isaura, E. R., Chen, Y.-C., \& Yang, S.-H. (2018). The Association of Food Consumption Scores, Body Shape Index, and Hypertension in a Seven-Year Follow-Up among Indonesian Adults: A Longitudinal Study. International Journal of Environmental Research and Public Health, 1-12.

Liu, X. (2016). Methods and Applications of Longitudinal Data Analysis. UK: Academic Press.

Nirmala, F., Kuntoro, \& Notobroto, H. B. (2013). Aplikasi General Linear Mixed Model (GLMM) pada Data Longitudinal Kadar Trombosit Demam Berdarah Dengue. Jurnal Biometrika dan Kependudukan, 131-139.

Nugroho, P. S., \& Wijayanti, A. C. (2018). Indeks Masa Tubuh dan Kaitannya Dengan Diabetes Melitus pada Umur lebih dari atau sama dengan 15 Tahun Di Indonesia, Studi Data Survei Kehidupan Keluarga Indonesia V. Jurnal Publikasi Kesehatan Masyarakat Indonesia, 12-15.

Pusponegoro, N. H., Rachmawati, R. N., Notodiputro, K. A., \& Sartono, B. (2017). Linear Mixed Model for Analyzing Longitudinal Data:A Simulation Study of Children Growth Differences. 2nd International Conference on Computer Science and Computational Intelligence 2017, ICCSCI 2017 (hal. 284-291). Bali: Procedia Computer Science.

Putri, R. F., Padmadisastra, S., \& Winarni, S. (2017). Analisis Data Longitudinal Dalam Desain Faktorial Menggunakan Linear Mixed Model. Seminar Statistika FMIPA UNPAD 2017 (SNS VI) (hal. 462-466). Bandung: ResearchGate.

Rizopoulus, D. (2012). Joint Models for Longitudinal and Time-to-Event Data With Application in R. New York: Chapman \& Hall/CRC Biostatistics Sseries.

Susanti, \& Bistara, D. N. (2018). Hubungan Pola Makan Dengan Kadar Gula Darah Pada Penderita Diabetes Mellitus. Jurnal Kesehatan Vokasional, 29-34. 